kobieta także na równi z mężczyzną może dokonywać rzeczy niezwykłych, wielkich, na chwałe swojej ojczyzny i innych ludzi.

W ostatnim artykule tego rozdziału mamy refleksje nad wzorem kobiety $w$ filmie socrealistycznym, gdzie autor Piotr Zwierzchowski zadaje pytania: ,Czy byly bohaterkami na tyle atrakcyjnymi, aby stać się wzorem dla milionów kobiet? Czy proponowany przez nie model życia godny był uwagi?"

W części trzeciej podane sa także rozliczne przykłady kobiet i ich ról oraz wpływu, jaki wywierały na otoczenie. Odnajdujemy tu kobiety działaczki społeczne, działajace w towarzystwach dobroczynnych, działaczki partyjne, Czerwonego Krzyża, czy też kobiety aktywne podczas I i II wojny światowej oraz kobietę w okresie powojennym. Na uwage zasługuje także przykład Amerykanki Jane Addams, która tak jak rozliczne Polki dla ludzi potrzebujących organizowały pomoc, tak ona w Ameryce niosła pomoc w wielu dziedzinach. Pomagajac wyzyskiwanym dzieciom, murzynom, kobietom, bezrobotnym, jednym stowem wszystkim, którzy w jej czasach takiej pomocy potrzebowali

Uczestnictwo kobiet w edukacji jest przedstawione w czwartej części recenzowanej pracy zbiorowej. Znajdziemy tu już w pierwszym artykule nawiazanie do Pana Tadeusza, gdzie na przykładzie bohaterek dziela Adama Mickiewicza, poznajemy w jaki sposób dziewczęta $z$ rodzin szlacheckich zdobywaly wiedze. Mamy także pokazany sposób, w jaki kobiety poprzez ksztalcenie dokonywały usamodzielnienia się, czyli emancypacji. W kolejnym artykule ukazany jest heroizm, z jakim kobiety w okręgu wileńskim w latach 1864 - 1915 organizowały tajne szkolnictwo polskie. Następny artykuł mówi nam o Marii Dzieżanowskiej, kobiecie która stała na czele
Zwiazku Unarodowienia Szkół. W jednym z artykułów odnajdujemy model obywatela, jaki stworzyła Helena Witkowska. Dobry obywatel - według niej - ,,musi być sprawiedliwym, męźnym, rozumnym, pracowitym i dzielnym człowiekiem"4 . Witkowska zwraca uwagę na rzecz najistotniejsza, że rodzina jest podstawa, na której buduje się człowiek $\mathrm{i}$ bez niej będzie on tylko drzewem bez korzeni, ponieważ korzenie sa genesis wszystkich pozytywnych cech jakich możemy oczekiwać od młodego obywatela.

Reasumujac, praca jak podaje sam redaktor, „nie wyczerpuje złożoności podjętego tematu". Jest za to ze względu na zawartosć materiałów źródłowych oraz ich walory poznawcze i różnorodność tematyczną cennym materiałem dla wszystkich, którzy zechca skorzystać z niniejszej publikacji. Z całą pewnością można tẹ pracę zarekomendować historykom wychowania i badaczom innych dziedzin nauk historycznych, którzy na swojej drodze badawczej będa poszukiwali obszernej pozycji poswięconej roli kobiety jako matki, żony, czy teź opiekunki.

Pracę tę można polecić także każdemu kto ceni sobie swój kraj ojczysty. Mamy tu bowiem wiele wspaniałych przykładów jak należy walczyć o polskość i jak naleźy ja kultywować. Możemy także znaleźć piękne przykłady heroicznej walki kobiet o polskość, która w chwili obecnej nie jest tak wielka wartością jak w minionych czasach.

Krzysztof Biniecki

1 „Kronika Rodzinna” 1881, t. IX, s. 149.

2 H. Bednarski, Spoteczna rola kobiet wiejskich, Bydgoszcz 1976, s. 63, s. 190.

3 August Hlond - Prymas Polski, Z Chrystusem w życie. Okruchy myślowe 1922 - 1948, wyb. I oprac. Ks. S. Kosiński SDB, Łódź 1984, s. $100-101$.

4 L. Dobrzyńska-Rybicka, H. Witkowska, Obywatelstwo jako podstawa zycia zbiorowego $w$ odrodzonej Polsce, Poznań 1931, s. 12.

\title{
Urszula Perkowska, Jubileusze Uniwersytetu Jagiellońskiego, Wydawnictwo i Drukarnia Secesja, Kraków 2000, ss. 394
}

W roku 2000 Uniwersytet Jagielloński świętował jubileusz 600 -lecia odnowienia. $\mathrm{Z}$ tej okazji ukazało się wiele wydawnictw przedstawiających dzieje najstarszej polskiej uczelni. $\mathrm{Na}$ listę publikacji poświęconych dziejom Uniwersytetu Ja- giellońskiego wpisała się po raz kolejny Urszula Perkowska oddając do rak czytelników pracę pt. Jubileusze Uniwersytetu Jagiellońskiego ${ }^{1}$.

Praca ukazała się w serii Biblioteka Krakowska (nr 140) i składa się z siedmiu rozdziałów 
oraz Aneksu. W nim zamieszczono nazwiska osób, którym nadano tytuł doktora honoris causa podczas kolejnych uroczystości. Ponadto treść pracy uzupełniaja fotografie będace ilustracją ważnych wydarzeń i osobistości życia naukowego Uniwersytetu.

Dwa pierwsze rozdziały Autorka poświęciła zagadnieniom fundacji uniwersytetu. W pierwszym zatytułowanym Podstawy fundacyjne Uniwersytetu przybliżone zostały główne założenia fundacji Kazimierzowskiej i Jagiellońskiej. Z kolei w rozdziale Pamięć o fundacjach Uniwersyteckich od XV do potowy XIX wieku jest mowa o kształtowaniu się polskiej świadomości, o ważności wiedzy, na temat powstania i odnowienia uczelni. Powołując się na dotychczasowe ustalenia Autorka stwierdza, że zainteresowanie tak ważnym wydarzeniem $w$ dziejach Polski zrodziło się stosunkowo późno. „Niezależnie od przeszkód losowych glównym powodem braku wcześniejszych, chociażby skromnych obchodów rocznicowych fundacji najstarszej polskiej uczelni był brak świadomości historycznej. Uniwersytet Krakowski przez długie dziesięciolecia nie wykazuje zbyt wielkiego zainteresowania własna przeszłościa, co też odbijało się na słabej znajomości dziejów Akademii wśród dawnych kronikarzy i dziejopisarzy" (s. 20). Polacy w przeciwieństwie do innych narodów, które czciły rocznice fundacji swych uniwersytetów, nie przywiazywali do tego wydarzenia zbyt dużej wagi. Ten fragment pracy jest ważny przede wszystkim dlatego, że Autorka prostuje błędy i nieścisłości, jakie popełniali autorzy prac na temat Akademii Krakowskiej.

Kolejny rozdział pt. Obchody 500-lecia powstania Akademii Krakowskiej (1864) przedstawia problemy burzliwych wydarzeń towarzyszących przygotowaniom jubileuszu. Trzeba zaznaczyć, że obchody tego jubileuszu przypadły na bardzo trudny okres w dziejach uczelni. Po zdławieniu autonomii Uniwersytetu kolejnymi rozporzadzeniami cesarskimi, grupa profesorów skupionych wokół J. Dietla i J. Majera czyniła starania o repolonizację Uniwersytetu. Działania patriotycznie nastawionych profesorów byly przeszkoda w zatwierdzeniu przez władze austriackie projektu obchodów jubileuszu. W programie obchodów władze zaborcze dostrzegały zagrożenia dla proaustriackiego charakteru uniwersytetu.
W obchody 500-lecia Akademii Krakowskiej wlączyło się Towarzystwo Naukowe, a szczególną aktywnościa odznaczył się Józef Majer, który był przewodniczacym komitetu jubileuszowego. Wybuch powstania styczniowego odbil się niekorzystnie na ostatniej fazie przygotowań. Pojawiły się glosy o konieczności przesunięcia uroczystości na późniejszy termin. Także władze austriackie przesłały do Senatu uczelni, zarzadzenia, wskazujące konieczność odłożenia jubileuszu na czas nieokreślony. Tak też $20 \mathrm{~V} 1864$ roku uczczono jubileusz 500-lecia Akademii Krakowskiej jedynie cichym nabożeństwem $\mathrm{w}$ kościele św. Anny. Uczelnia nie otrzymała żadnych gratulacji z zagranicy. Pismo gratulacyjne przesłał jedynie rektor Szkoły Glównej Józef Mianowski. Ucierpialy $\mathrm{z}$ powodu tej sytuacji wydawnictwa jubileuszowe. Dlatego też prezes TN J. Majer postanowil, iż wszelkie prace opublikowane $w$ roku 1864 dedykuje Uniwersytetowi. Co więcej wydawnictwa rocznicowe przesłano, jak na ironię, A. Schmerlingowi, który najbardziej przyczynił się do braku jubileuszu. Pomimo upływu właściwego terminu, profesorowie przedkładali kolejne propozycje obchodów jubileuszu, przewidując ich realizację $w$ okresie inauguracji roku akademickiego. Wszelkie działania w tym kierunku napotykały na dalsze opory Austrii, która nie zamierzała dopuścić do patriotycznych manifestacji. Jednak zdaniem Autorki pracy, ,Niedoszły jubileusz Wszechnicy Krakowskiej unaocznił również patriotyczna postawę dużej części grona pedagogicznego uczelni. Ta nieugięta postawa wielu profesorów, walka o polskość Uniwersytetu i podkreślanie jego narodowej tradycji przyczyniła się do pozbawienia katedry dwóch uczonych, ... prawnika Michała Koczyńskiego i najwybitniejszego rektora tego okresu, Józefa Dietla" (s. 79).

Ważnym wydarzeniem w dziejach Akademii Krakowskiej bylo otwarcie gmachu Collegium Novum, o którym mowa w rozdziale IV pt. Otwarcie gmachu Collegium Nowvm w czerwcu $1887 \mathrm{r}$. W zamiarach organizatorów uroczystość ta miała być częściowym zadośćuczynieniem niedoszłych do skutku uroczystości 500-lecia Akademii. Był to czas nieco bardziej sprzyjajacy wszelkim inicjatywom, bowiem Uniwersytet uzyskal pewna autonomię. Marzeniem organizatorów było, aby nadać temu wydarzeniu charakter ogólnopolski. Co więcej, jak pisze Autorka, 
„Uroczystości otwarcia Collegium Novum były, ... łącznikiem pomiędzy niedoszłym jubileuszem 500-lecia fundacji Kazimierza Wielkiego a również pięciowiekową rocznica odnowienia uczelni przez Władysława Jagiełle, przypadająca na rok 1900" (s. 117).

W innej atmosferze trwały przygotowania do rocznicy 500-lecia odnowienia Akademii - rozdział V pt. Jubileusz 500-lecia odnowienia Uniwersytetu $w$ roku 1900. Jubileusz 500-lecia odnowienia Akademii Krakowskiej był elementem jednoczącym naród. Odnosi się także wrażenie, czytajac niniejsza pracę, że była to pewnego rodzaju manifestacja patriotyczna. Przygotowania do pięćsetnej rocznicy rozpoczęto dosyć wcześnie, gdyż pierwszą inicjatywę $w$ tej sprawie zgłoszono w 1887 roku. Od tego czasu trwaja prace nad powołaniem komitetu jubileuszowego, opracowaniem programu uroczystości i zgromadzeniem funduszy. Wystosowana w 1896 roku z inicjatywy S. Smolki prośba do wiedeńskiego Ministerstwa Oświaty o przyznanie subwencji nie spotkała się ze zrozumieniem władz zaborczych. W tej sytuacji rektor S. Smolka wydał odezwę do profesorów i docentów z prośba o dobrowolne opodatkowanie się na cele jubileuszu, co spotkało się z pozytywna reakcja grona naukowego. Święto krakowskiej uczelni wg jej inicjatorów miało być świętem nauki polskiej. Dla uczczenia jubileuszu zwołano do Krakowa III Zjazd Historyków Polskich. Dużą aktywność w przygotowaniach do święta wykazała mlodzież akademicka skupiona w Kole Historyków, którego przewodniczacym byl J. Ptaśnik. Nie zapomniano o udziale delegacji szkolnych, w tej sprawie zwrócono się o pozwolenie do Rady Szkolnej Krajowej. Kontrowersyjna sprawa dla wielu uczonych, m.in. rektora S. Tarnowskiego, był udział w centralnych uroczystościach delegacji robotniczych i kobiet.

Uroczystości jubileuszowe rozpoczęły się 6 czerwca 1900 roku w Katedrze Wawelskiej. W głównym dniu uroczystości 7 czerwca 1900 roku Kraków przybrał odświętny wygląd, a punktem centralnym było odsłonięcie pomnika Mikołaja Kopernika na dziedzińcu Collegium Novum. Przebieg tej uroczystości U. Pekowska podsumowała: „Jubileusz pięćsetlecia odnowienia Uniwersytetu Jagiellońskiego, obchodzony w roku 1900 , był wielkim świętem nauki polskiej, miasta Krakowa i wszystkich Polaków" (s. 167).
Autorka kolejny VI rozdział książki pt. Jubileusz 550-lecia Wydziatu Teologicznego Uniwersytetu Jagiellońskiego, poświęciła rocznicy powołania Wydziału Teologicznego UJ. Wprawdzie trzeba zaznaczyć, że profesorowie tego Wydziału brali czynny udział w przygotowaniu jubileuszu 1900 roku (ks. J. Fijałek, ks. W. Chotkowski). Rocznice utworzenia Wydziału polączono ze Zjazdem Polskiego Towarzystwa Teologicznego zwołanego do Krakowa w dniach 6-8 kwietnia 1948 roku. Pierwszy dzień zjazdu poświęcono obchodom jubileuszu. $\mathrm{Na}$ akademię rocznicowa przeznaczono jedynie dwa referaty, biskupa M. Godlewskiego i ks. T. Glemmy. W następnych dniach obrady polskich teologów przebiegały wg programu zjazdu. Jubileusz i zjazd odbywał się w trudnej atmosferze politycznej Polski, wyrażało się to $w$ niechętnym stosunku władzy politycznej do studiów teologicznych. Jednak zdaniem Autorki, jubileusz i zjazd zostal przygotowany wzorowo. Chociaż pojawiły się słowa krytyki skierowane w stosunku do programu zjazdu i zgłoszonych referatów, wyraził je o. J. Woroniecki. Mimo wszystko zjazd i jubileusz wpłynął pozytywnie na działalność wydawnicza Wydziału.

Ostatni, VII rozdział Jubileusz 600-lecia Akademii Krakowskiej w roku 1964 prezentuje okoliczności przygotowania i przebieg okragłej rocznicy 600-lecia najstarszej polskiej uczelni. W roku 1964 Uniwersytet Jagielloński obchodził po raz pierwszy $w$ swoich dziejach rocznicę fundacji przez Kazimierza Wielkiego. Warto zaznaczyć, iż pierwszy impuls $w$ tej sprawie wyszedł od H. Barycza już w 1955 roku. W latach 60-tych XX wieku Uniwersytet znajdował się w zupełnie innej sytuacji politycznej, społecznej i kulturowej aniżeli w czasie wspomnianych wcześniej rocznic jego założenia lub odnowienia. U. Perkowska stwierdza, iż „Od roku 1949 rozpoczęło się planowe rozbijanie dawnej struktury Akademii Krakowskiej, od której odłączano kolejne wydziały.... $\mathrm{Na}$ ich miejsce powstawały samodzielne wyższe akademickie szkoły zawodowe. Całkowitej likwidacji uległa Szkoła Nauk Politycznych i Studium Spółdzielcze" (s. 197). Co więcej „Mimo pozorów autonomii, obieralności władz akademickich, Uniwersytet zależny był całkowicie od władz partyjno-rzadowych, które miały decydujący głos w sprawach budżetowych, jak też obsadzie katedr, tworzeniu nowych kierun- 
ków studiów czy limicie przyjęć studentów" (s. 200). To wszystko mialo ogromny wpływ na przygotowania i przebieg 600-lecia Uniwersytetu. „Czuwanie" władzy politycznej nad przygotowaniem uroczystości widoczne było $w$ wielu zakresach. Wpływ polityki uwidocznił się w zmianach: programu obchodów, programu wydawniczego, listy zaproszonych gości, jak i kandydatów do zaszczytu doktora honoris causa. Członkowie powolanego komitetu jubileuszowego czynili często osobiście starania o pozyskanie funduszy i poparcie dla różnych inicjatyw zwiazanych $\mathrm{z}$ tym wydarzeniem. Utrudnieniem było zbyt długie oczekiwanie na zatwierdzenie programu obchodów, bowiem przeslany do Ministerstwa Szkolnictwa Wyższego w czerwcu 1961 roku program centralnych uroczystości, został zatwierdzony 12 VI 1963 roku. Ponadto w trakcie oczekiwania na decyzję dokonano szeregu zmian w programie.

Opisane przez Autorkę jubileusze, bez względu na ich przebieg, który w zasadniczej mierze uzależniony był od sytuacji politycznej, zawsze przynosiły określone wartości. Jeżeli nie w sensie powiększenia dorobku naukowego, to sensic ksztaltowania świadomości narodowej Polaków, a także popularyzacji wiedzy o kulturze polskiej na arenie międzynarodowej.

W sumie lektura ksiażki przynosi informacje odnoszące się do: sytuacji politycznej, która towarzyszyła przygotowaniom uroczystości jubileuszowych i przebiegowi, kondycji naukowej uczelni w okresie poprzedzającym wydarzenia rocznicowe, zasług grona profesorskiego w nadaniu uroczystościom nie tyle charakteru obrzędowego ile naukowego, treści i charakteru wydawnictw, udziału uczonych zagranicznych i reakcji świata nauki na kolejne rocznice, udziału młodzieży studiującej w uroczystościach, reakcji opinii publicznej na przygotowania i przebieg kolejnych jubileuszy, znaczeniu uroczystości jubileuszowych w ożywieniu życia naukowego uniwersytetu.

Wreszcie należy dodać, że opis uroczystości jubileuszowych stał się okazja do ukazania życia kulturalnego Krakowa i jego niepowtarzalnej atmosfery. Jednocześnie Autorka swoja pracą dowiodla, iż kolejne uroczystości jubileuszowe Uniwersytetu Jagiellońskiego nie były jedynie forma jeszcze jednego „obrzędu polskiego”. Były ważnym wydarzeniem kulturalnym i naukowym Polski. Należy żywić nadzieję i oczekiwać, iż kolejna publikacja Urszuli Perkowskiej będzie poświęcona jubileuszowi 600-lecia odnowienia Akademii Krakowskiej.

Wtadystawa Szulakiewicz

1 Warto przypomnieć wcześniejsze prace tej Autorki m.in: Ksztaltowanie się zespotu naukowego w Uniwersytecie Jagielloniskim (1860-1920), Wroclaw 1975; Uniwersytet Jagielloniski w latach I wojny swiatowej, Kraków 1990, Studentki Uniwersytetu Jagielloniskiego w latach 1894 - 1939. W stulecie immatrykulacji pierwszych studentek, Kraków 1994; Studia i kursy zawodowe na Uniwersytecie Jagielloniskim w latach 1868/69 - 1938/39, Kraków 1995.

\section{Zygmunt Ruta, Jan Ryś, Dzieje I Liceum Ogólnokształcącego w Tarnowie do 1939 roku, Kraków 1999, s. 259}

Nakładem oficyny wydawniczej ,Edukacja” ukazała się cenna praca autorstwa Zygmunta Ruty i Jana Rysia. Książka jest poświęcona dziejom I Liceum Ogólnoksztalcącego im. Kazimierza Brodzińskiego w Tarnowie. Zawarta w tytule data 1939 wyznacza końcowa cezurę czasowa, wskazując na zasięg chronologiczny przeprowadzonych przez autorów badań nad historia szkoły.
Praca jest pod wieloma względami wyjąkowa. Przede wszystkim przynosi ogrom rzetelnych informacji o dziejach I Liceum Ogólnokształcacego $w$ Tarnowie. Oryginalnošć dzieła polega na wiazaniu dziejów szkoły z dokonującymi się w tym czasie przemianami społecznymi, politycznymi i kulturalnymi.

Wartość pracy podnosi również bogata baza źródlowa, która w przeważającej mierze stanowią 